УДК [339.138:339.372.2] (477)

\title{
БУДНІКЕВИЧ ІРИНА,
}

доктор економічних наук, професор

Чернівецького національного університету імені Юрія Федьковича

\section{ЧЕРДАНЦЕВА ІРИНА,}

кандидат економічних наук, дочент

Чернівещького національного університету імені Юрія Федьковича

\section{ФОРМУВАННЯ КОНКУРЕНТНИХ СТРАТЕГІЙ РОЗВИТКУ ПІДПРИЕМСТВ РОЗДРІБНОЇ ТОРГІВЛІ В ІНСТИТУЦІОНАЛЬНОМУ СЕРЕДОВИЩІ}

\begin{abstract}
У статті розглядаються можливості застосування сучасних підходів до формування конкурентних стратегій розвитку підприємств роздрібної торгівлі з урахуванням впливу інституціонального середовища, орієнтованого на використання маркетингових інструментів при розробці принципів адаптації ритейлерів до змінних умов ринку. Узагальнені сучасні тенденції розвитку ринку роздрібної торгівлі України та зроблено висновок про наявність негативних трендів, які визначають стратегії операторів роздрібної торгівлі. Описано принцип роботи нових операторів ринку роздрібної торгівлі, які, заходячи на ринок як інноватори, поступово переходять до традиційних "усереднених, типових" схем роботи. Зроблено висновок про необхідність ціннісної орієнтації (винайдення й обслуговування додаткової, унікальної корисності для споживачів) конкурентних стратегій розвитку роздрібного підприємства.
\end{abstract}

Ключові слова: інституціональне середовище; концепції розвитку; роздрібна торгівля; маркетингові інструменти; конкурентні стратеаії; стратеаії розвитку роздрібної торгівлі; ринок роздрібної торгівлі.

Постановка проблеми. Загострення проблеми ресурсного забезпечення, яка виникла внаслідок диспропорцій у соціально-економічному розвитку регіонів, ускладнило можливості ведення бізнесу на основі територіальної автономності та актуалізувало необхідність отримання ресурсів "на стороні". Зрозуміло, що безоплатно законним способом отримати ресурс неможливо, тому динамічний розвиток світового ринку торгівлі перетворив світ на єдиний економічний простір і зумовив взаємозалежність економічних суб'єктів. При цьому боротьба за вплив нових та старих центрів економічного зростання призвела до появи кризових явищ у світових економічних, соціальних та політичних процесах, усунення яких вимагає перегляду домінуючої некласичної теорії економічного розвитку на користь інституціоналізму.

Інституціоналізм набирає силу як домінуюча точка зору на правила розвитку суспільства, що приходить на зміну характерній для індустріального суспільства неокласичній визначеності. Торгівля, виступаючи з'єднувальною ланкою між економічними суб'єктами в ринковій економіці, першою відчуває необхідність урахування інституційного підходу.

Відмінності та особливості соціально-економічного розвитку країн із розвиненою ринковою економікою та країн із перехідною економікою, основні тенденції розвитку світової економіки, серед яких найважливішою є глобалізація світового простору, загострення конкуренції, урізноманітнення ії фоорм та інтенсивність прояву, поширення процесів експансії та концентрації рин- ків обумовлюють необхідність дослідження перспектив подальшого розвитку, а також розробки концептуальних засад конкурентних стратегій підприємств сфрери торгівлі в інституційному середовищі як складової частини ринкового простору України.

Аналіз останніх досліджень і публікацій з проблеми. Наукові роботи таких відомих зарубіжних вчених, як І. Ансофрф [1], А. П. Терлуолл, П. Пачеко-Лопес [2], Е. Говард [3], Дж. Рейнольдс [4] та інших дають можливість ознайомитися 3 досвідом застосування інституційних підходів у вирішенні проблем формування та реалізації стратегій розвитку підприємств торговельної сорери, де вже досягнуті значні успіхи. За останні роки з'явився цілий ряд наукових публікацій, які підготовлені вітчизняними вченими і вченими інших країн та присвячені питанням застосування стратегічних підходів у роздрібній торгівлі. Це роботи таких авторів, як А. Самлі [5], М. Д. Бедринець [6], О. В. Литвинова [7], Д. Москаленко [8], Д. Нестеров [9], В. О. Швестко [10] та ін. Однак питанням формування стратегій розвитку вітчизняних торговельних підприємств в інституційному середовищі присвячено занадто мало наукових публікацій, тоді як важливість окресленої проблеми зростає і на практиці існує велика потреба в таких дослідженнях.

Метою статті $€$ визначення концептуальних засад формування конкурентних стратегій торговельних підприємств з урахуванням інституційних поглядів на принципи взаємодії ринкових суб'єктів, які діють в одному економічному просторі. 
Виклад основного матеріалу. Сучасна інституціональна теорія $€$ економічним аналізом ролі інститутів та їхнього впливу на господарство на основі принципів раціональності та методологічного індивідуалізму. Загалом сучасний інституціоналізм характеризують такі погляди:

а) "інституції мають значення", тобто вони впливають на результати функціонування й динаміку економіки;

б) людська поведінка не характеризується повною (всеосяжною) раціональністю; її найважливішими характеристиками $є$ обмежена раціональність та опортунізм;

в) здійснення ринкових трансакцій, тобто функціонування цінового механізму та інших атрибутів ринкової економіки, передбачає врахування додаткових трансакційних видатків.

Інституційне середовище - це сукупність базових політичних, соціальних та юридичних правил, які утворюють основу для виробництва, обміну й розподілу, безпосередньо торкаючись і такого виду діяльності, як роздрібна торгівля.

Умовою для утворення світового ринку торгівлі послужив технічний і науковий прогрес транспорту і зв'язку, які в поєднанні з торговельними відносинами перетворили світ на єдиний економічний простір. Торгівля це з'єднувальна ланка між виробником ресурсів (товарів) і споживачем (покупцем), що забезпечує виробничий ланцюг перетворення "гроші-товар-гроші". Найчастіше виробник не завжди має можливість (як фрізичну, так і економічну) донести свій продукт до кінцевого споживача. У той же час виробники є споживачами ресурсів з метою подальшого відтворення, тому так само $є$ покупцями і закуповують ресурси (товари) не тільки у постачальників-виробників, але й у більшості випадків через торговельну оптову мережу.

Філософською основою інституціоналізму $є$ постулат про невизначеність розвитку. Постулат невизначеності найтіснішим чином поєднаний з ідеєю суб'єктивізації та індивідуалізації постіндустріального суспільства. Усе це дуже важливі компоненти нової парадигми, хоча вони й не вичерпують проблеми. Інституційна економіка відкидає методи маржинального й рівноважного аналізу, беручи на озброєння еволюційно-соціологічні методи. Відносини між людьми, що розглядаються крізь призму взаємовигідного обміну, називають контрактною (договірною) парадигмою. Контрактна (договірна) парадигма першого напряму може реалізовуватися як через інституційне середовище (вибір правил гри: соціальних, юридичних та політичних) тобто ззовні, так і через відносини, що лежать в основі організацій, тобто зсередини.

Інституційне середовище $є$ сукупністю базових політичних, соціальних та юридичних правил, які утворюють основу для виробництва, обміну й розподілу, безпосередньо торкаючись і такого виду діяльності, як роздрібна торгівля [7].

Багато хто вважає, що роздрібна торгівля в основному пов'язана з продажем матеріальних (тобто фрізичних товарів). Однак це не зовсім так. Роздрібна торгівля - це продаж не тільки матеріальних товарів, а й послуг. Купівля певної послуги (наприклад, стрижка або подорож літаком) може бути основною метою споживача або складовою частиною покупки будь-якого матеріального товару (у цьому випадку йдеться, наприклад, про доставку товару додому або про навчання користуватися цим товаром). Роздрібна торгівля зовсім не обов'язково передбачає продаж товарів у магазині. Вона включає, зокрема, замовлення товарів поштою або телефоном, прямий продаж товарів у споживачів удома (або в офісі), здійснення трансакцій через мережу Інтернет, а також продаж за допомогою торговельних автоматів. Більше того, роздрібна торгівля не обов'язково передбачає наявність роздрібного торговця як такого.

Фірми-виробники, імпортери, некомерційні фірми та оптові торговці виконують фрункції роздрібних торговців, якщо продають товари та послуги кінцевому споживачеві. 3 іншого боку, покупки, які здійснюються фірмами-виробниками, оптовими торговцями та іншими організаціями для власного користування або для наступного перепродажу, не мають ніякого відношення до роздрібної торгівлі.

При застосуванні компанією-ритейлером стратегії, орієнтованої на споживача, основним показником її діяльності $\epsilon$ цінність продукції для споживачів, а також чіткі й зрозумілі цілі. Сукупність цих показників укладається в маркетингову концепцію (marketing concept), яку можна трансформувати в концепцію роздрібної торгівлі. Концепція роздрібної торгівлі (retailing concept) складається з чотирьох елементів - орієнтація на споживача, скоординовані дії, орієнтація на цінність, прагнення досягати цілей. Сутність концепції роздрібної торгівлі полягає в такому: орієнтація на споживача (роздрібний торговець визначає характеристики й потреби своїх клієнтів і прагне до якнайповнішого задоволення цих потреб); координування дій (роздрібний торговець координує всі свої плани та дії, об'єднуючи ïx в одне ціле, для досягнення максимальної ефективності роботи); орієнтація на цінність (роздрібна форма, або дисконтний магазин, або елітний бутік - усі прагнуть забезпечити високу цінність для своїх клієнтів, при цьому під цінністю мається на увазі відповідність цін якості товарів і рівню обслуговування клієнтів); прагнення домагатися цілей (роздрібний торговець ставить перед собою цілі, а потім використовує певну стратегію для їх досягнення).

На жаль, такої концепції дотримуються далеко не всі роздрібні торговці. Деякі з них проявляють байдужість до потреб покупців, планують свою діяльність навмання, встановлюють ціни, що не відображають справжньої цінності товарів, і не прагнуть ставити перед собою чіткі та досяжні цілі. Занадто часто роздрібні торговці не сприймають зміни або просто копіюють стратегії, що використовуються їхніми конкурентами.

Деякі роздрібні торговці не прагнуть досліджувати переваги споживачів, вивчати їх думки та побажання, а цілком покладаються на звіти постачальників або свій попередній досвід продажів. У той же час концепцію роздрібної торгівлі не так вже складно засвоїти та прийняти на озброєння. Це означає, що потрібно спілкуватися $з$ покупцями й ураховувати їхні потреби; мати послідовну стратегію (наприклад, у магазинів вищого розряду може бути така стратегія: пропозиція одягу тільки від відомих дизайнерів, велика кількість торговельного персоналу, привабливі виставки товару й ціни вище середнього рівня); встановлювати справедливі, з точки зору споживача, ціни (відповідність ціни і якості товару); працювати на досягнення значущих, конкретних i реальних цілей.

Однак концепція роздрібної торгівлі - це лише стратегічний дороговказ до дії. Вона не зачіпає внутрішніх можливостей фірми або її конкурентних переваг, пропонуючи лише загальну схему планування.

Існують різні підходи до вивчення роздрібної торгівлі. Інституційний підхід побудований на описі типів роздрібної торгівлі та їх розвитку. При використанні фрункціонального підходу концентруються на діях, які виконуються роздрібними фрірмами (таких як закупівля то- 
варів, формування цін та робота з кадрами). У центр стратегічного підходу, як ми вже зазначали вище, визначення роздрібної фрірми, постановка цілей, орієнтація на відповідний споживчий ринок, вироблення спільного плану, реалізація інтегрованої стратегії й регулярне корегування.

Логічно вважати, що роздрібний торговець повинен ураховувати складність і мінливість обстановки, в якій йому доводиться діяти, і своєчасно адаптуватися до майбутніх змін. При цьому необхідно брати до уваги не тільки можливості, які відкриваються внаслідок таких змін, а й загрози, які можуть ці зміни супроводжувати. Стратегічний підхід у роздрібній торгівлі передбачає, що будь-який роздрібний торговець повинен вивчати своїх конкурентів, постачальників, економічні фактори, зміни споживчого ринку, ринкові тенденції, правові обмеження та інші елементи. Роздрібна фрірма може розраховувати на успіх, якщо її конкурентні переваги відповідають можливостям середовища, в якому їй доводиться діяти; якщо їй удається усунути (або, принаймні, мінімізувати) свої слабкі сторони; якщо її плани не тільки спрямовані в майбутнє, але й ураховують попередній досвід.

Роздрібна торгівля включає підприємства і людей, що беруть участь у процесі фрізичного переміщення товарів і послуг, а також у передачі права власності на ці товари та послуги від виробника споживачу. У каналі розподілу роздрібні компанії відіграють важливу роль сполучної ланки між виробниками, оптовими торговцями та іншими постачальниками, з одного боку, кінцевим споживачем - з іншого. Вони отримують певний асортимент товарів від різних постачальників і пропонують ці товари споживачам. Роздрібні торговці взаємодіють як зі споживачами, так і з іншими учасниками каналу розподілу. Вони можуть доставляти, зберігати, маркувати, рекламувати товари й виконувати передоплату цих товарів. Вони здійснюють трансакції (торговельні угоди) зі споживачами і часто надають їм певн послуги.

Стратегія роздрібної торгівлі - це загальний план, відповідно до якого роздрібна фрірма здійснює свою діяльність. Виділяють такі шість етапів стратегічного планування: визначення типу бізнесу, яким належить займатися; постановка цілей; визначення споживчого ринку; розробка загального довгострокового плану; реалізація інтегрованої стратегії; регулярна оцінка ефективності своєї діяльності та внесення необхідних коригувань.

Використання концепції маркетингу в роздрібній торгівлі (якщо вона застосовується до роздрібної торгівлі, то називається концепцією роздрібної торгівлі), видається можливим при зміщенні основного акценту на такі поняття, як загальні враження покупців від роз- дрібної фрірми, обслуговування клієнтів та роздрібна торгівля на основі відносин.

Але, незважаючи на очевидність і простоту концепції роздрібної торгівлі, багато фрірм випускають 3 уваги ті чи інші її елементи. Загальні враження від роздрібної фірми включають всі елементи роботи роздрібної фірми, які стимулюють (заохочують) або, навпаки, стримують споживачів під час їх контакту з певною фрірмою. Деякі з цих елементів підвладні роздрібному торговцю, а інші - ні. Під обслуговуванням клієнтів розуміється цілком певна, хоча іноді й невловима діяльність, виконувана роздрібним торговцем поряд із продажем основних товарів і послуг.

Загальну тенденцію, що спостерігається сьогодні на ринку роздрібної торгівлі України, неможливо охарактеризувати як позитивну. У 2015 р. сталося вагоме скорочення продажу в більшості сегментів роздрібної торгівлі, роздрібний товарооборот у грошовому вираженні зменшився на 17 \%. У січні-вересні 2015 р. загальний оборот торгівлі склав 1579,4 млрд гривень, що свідчить про зменшення обороту роздрібної торгівлі (на $22,3 \%$ ) та обороту оптової торгівлі (на 14,0 \%) [10].

Оборот роздрібної торгівлі у 2015 р., за офріційними даними, упав на 21,4 \% (за січень-листопад, у порівнянні з показником за аналогічний період 2014 р. у порівнянних цінах, у національній валюті) (рис. 1).

Це найгірша динаміка обороту у вітчизняному ритейлі за останнє десятиліття. Під час попередньої кризи, у 2009 р., просідання відзначалося лише на 16,6 \% (рис. 2). Роздрібні підприємства, базари й фрізособипідприємці, за оцінками Держстату, за 11 місяців 2015 р. так і не наторгували на трильйон - виторг склав лише трохи більше 918 млрд грн. Трохи краще йдуть справи в оптовій торгівлі. Тут оборот підприємств за січень - листопад 2015 р. у порівнянних цінах упав лише на $13,3 \%$, та й абсолютний його показник вже перевищив 1,07 трлн грн [8]. Відзначають дослідники й зростання частки неорганізованої торгівлі в розпал нинішньої кризи. У структурі роздрібного товарообороту, за оцінками експертів, на частку такої торгівлі вже припадає понад $53 \%$.

Для кожного окремого сегменту ринку роздрібної торгівлі причини зменшення продажу різні. У сегменті "преміум" спостерігався стабільний розвиток та відвойовування частки ринку між конкурентами. Ситуація в "середньому" сегменті ринку роздрібної торгівлі зовсім інакша - понад 70 \% покупців перейшли до сегменту "середній мінус", почавши робити більшу кількість покупок в дискаунтерах або в місцях неорганізованої торгівлі, причиною цього стала різниця витрат на товари. У структурі обороту роздрібної торгівлі на організовані та неформальні ринки припадає 31,0 \% обсягів продажу. Частіше споживач не задоволений місцями

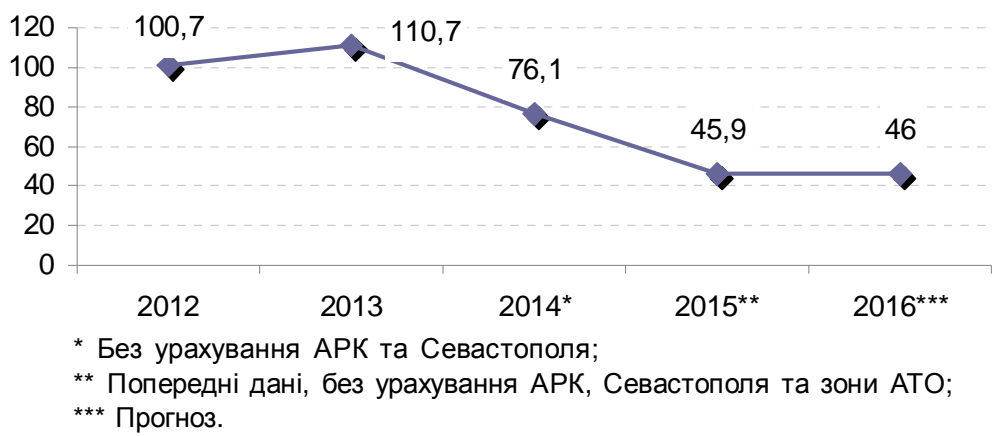

Рис. 1. Динаміка обороту роздрібної торгівлі України за 2012-2015 рр., млрд грн [складено за даними: 11]. 


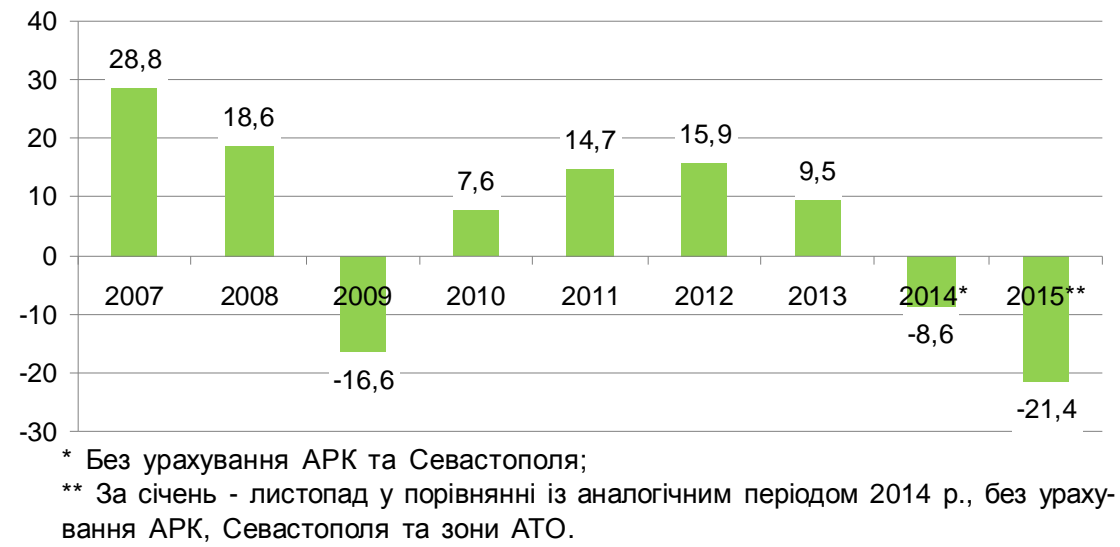

Рис. 2. Динаміка падіння обороту роздрібної торгівлі України за 2007-2015 рp., (\% порівняно із попереднім роком) [складено за даними: 8].

неорганізованої торгівлі для закупівлі товарів та намагається повернутися до магазинів, але фрінансове становище не дозволяє цього зробити. Таким чином, поведінка споживача показує, що роздрібним корпоративним мережам потрібно знижувати ціни, наповнювати свій асортимент новими товарами за більш вигідними цінами для споживача [8].

У структурі продажів торговельних мереж, за даними 2015 р., домінують окремі магазини, що складають близько 68 \% від усіх продажів. Прогнозується, що в кризовий час торговельні мережі робитимуть акцент на розвитку "дискаунтерів" і магазинів "біля будинку", частка яких у структурі зараз становить $9 \%$ і 0,8 \% відповідно. Частки форматів "супермаркет" та "гіпермаркет" приблизно однакові - 10 \% та $11 \%$ відповідно.

Лідерами за роздрібним товарооборотом $є$ Дніпропетровська, Одеська, Харківська, Київська та Львівська області. Збільшення роздрібного товарообороту підприємств цих областей відбулося на 12,6\%, $16 \%$, $18,4 \%, 21,9 \%, 27,11 \%$ відповідно. Роздрібний товарооборот Києва займає вагому частку в сукупному значенні роздрібного товарообороту підприємств України, тому що складає 20,4 \% від суми загального товарообороту. За січень - серпень 2015 р. товарооборот Києва збільшився на 21,2 \% порівняно з цим же періодом y 2014 p. [9].

Корпоративні роздрібні торговельні мережі орієнтуються на споживача та його можливості, тому переважну кількість відкритих магазинів складають магазини фрормату "біля будинку", які стали більш привабливими для покупця останнім часом. Згідно з дослідженням Shopper Trends, що проводиться компанією Nielsen один раз на рік в Україні, динаміка купівельної поведінки у 2015 р. змінилася: споживачі стали менше відвідувати магазини для того, щоб зробити більшу закупівлю продуктів про запас (раз на місяць або рідше). За останній рік акцент змістився більше на покупки за щоденними потребами або для приготування їжі [10].

У сучасних умовах підтримка та підвищення конкурентоспроможності підприємств торгівлі формується переважно інструментами маркетингу стосовно асортименту товару, умови гарантійного та післяпродажного обслуговування, ціни, якості (продукту та торговельних послуг) та умов продажу. Від якості торговельних послуг (а до них відносяться зручне для споживача розташування, доступність товару для ознайомлення, компетентність і ввічливість персоналу підприємства торгівлі тощо) багато в чому залежить величина попиту на товар при однакових цінових характеристиках у конкуруючих підприємств. Конкурентну перевагу, яка засно- вана на диференціації послуг, скопіювати набагато важче, а нематеріальність послуги створює і труднощі, і великі можливості для диференціації.

\section{Висновки}

Сьогодні стратегія розвитку нових операторів роздрібної торгівлі полягає в орієнтації створення пропозиції торговельних операцій, які характеризуються низьким прибутком і низькою ціною, але згодом вони включаються в торговельні операції з вищими цінами й великим набором послуг, стаючи, по суті, такими ж "звичайними" роздрібними торговцями, як і ті, яких вони замінили.

Попри падіння платоспроможного попиту й орієнтацію споживачів на низькі цінові пропозиції, рівень обслуговування дуже сильно впливає на загальні враження українців від роздрібної фрірми. Тому формування відносин зі споживачами означає, що роздрібні фрірми повинні прагнути створювати й підтримувати довготривалі зв'язки зі своїми клієнтами, а не поводитися так, немовби кожна чергова покупка в їхньому магазині вчиняється абсолютно незнайомою для них людиною. Справжніми переможцями у сфері роздрібної торгівлі стають завдяки: 1) творчому мисленню; 2) правильному вибору місця (саме в такому порядку). Ці два моменти визначають, наскільки високою (або низькою) буде ефективність роботи організації роздрібної торгівлі.

Орієнтації на нововведення у стратегії розвитку роздрібної торгівлі в інституціональному середовищі можна частково пояснити концепцією кругообігу ритейлу. Відповідно до цієї концепції нові форми роздрібної торгівлі починаються як торговельні операції низького рівня, що характеризуються невеликим прибутком, низькою ціною й так званою "торговельною фішкою" оригінальною технологічною або маркетинговою новацією. Вони змагаються з респектабельними роздрібними торговцями, які досягли успіху, відпустивши ціни i, тим самим, збільшивши прибуток. Намагаючись залучити покупців, нові роздрібні торговці змушені підвищувати рівень обслуговування, пропонуючи все нові й нові послуги, але при цьому все більше надаючи перевагу "усередненим, типовим" технологічним та маркетинговим інструментам. У свою чергу, збільшення витрат на обслуговування призводить до зростання цін. Зрештою ці нові роздрібні торговці стають точно такими, як і ті традиційні роздрібні торговці, яких вони замінили. І знову все починається спочатку: з'являються нові типи підприємств роздрібної торгівлі, вони встановлюють низькі ціни й задовольняються спочатку порівняно невисоким прибутком. 
Таким чином, часткове переформатування сучасної структури роздрібної торгівлі в Україні й орієнтація стратегій розвитку більшості гравців ринку на "економ"-пропозицію та "економ"-формат цілком вкладається в концепцію кругообігу роздрібної торгівлі, пояснюючи як початковий успіх, так і наступні невдачі "дискаунтерів", магазинів-гуртівень та магазинів біля будинку, а також нещодавній успіх роздрібної торгівлі за заниженими цінами

На нашу думку, намагаючись сформувати довготривалу стратегію розвитку роздрібного підприємства, керівництву фірм слід більше уваги приділяти винайденню та обслуговуванню додаткової, унікальної корисності, яка $€$ цінною для споживацької аудиторії, а не змінювати формат, керуючись лише маржинальним прибутком. Тільки чітке позиціювання унікальної корисності, яку знайде покупець у конкретному магазині, стане основою його тривалої купівельної лояльності й забезпечить роздрібній фірмі стабільне функціонування навіть при негативних тенденціях на ринку, а орієнтація лише на цінову різницю стимулюватиме споживачів до постійного пошуку нових "цінових спокус" в інших роздрібних точках і знову запустить "колесо" роздрібної торгівлі вже з іншими гравцями.

\section{ЛІТЕРАТУРА}

1. Ansoff $\mathrm{H}$. Igor. Strategic management of technology / H. Igor Ansoff // Journal of Business Strategy. - 1987. - Vol. 7, Iss: 3. - Pp. 28-39. doi: 10.1108/eb039162

2. Thirlwall A. P. Trade Liberalisation and The Poverty of Nations / A. P. Thirlwall, Penélope Pacheco-López. - Cheltenham : Edward Elgar, 2009. - 264 p. doi: 10.4337/9781848444010
3. Howard E. Retail internationalization: how to grow / Elizabeth Howard // Retail Strategy. The view from the bridge. - 2004. P. 96-118. doi: 10.1016/b978-0-7506-5696-2.50007-6

4. Reynolds J. Introduction to retail strategy / Jonathan Reynolds // Retail Strategy. - 2004. - P. 3-22. doi: 10.1016/b978-0-7506 5696-2.50003-9

5. Samli A. C. Coping with Retail Giants. Gaining an Edge Over Discounters / A. Coskun Samli. - Palgrave Macmillan US, 2015. 198 p. doi: $10.1057 / 9781137476340$

6. Бедринець М. Д. Фінансове забезпечення діяльності малих підприємницьких структур : автореф. дис. на здобуття наук. ступеня канд. екон. наук : спец. 08.04.01 "Фінанси, грошовий обіг і кредит" / М. Д. Бедринець ; Національна академія держ. податкової служби України. - Ірпінь, 2004. - 19 с.

7. Литвинова О. В. Концепция развития розничной торговли в институциональной среде [Електронний ресурс] / О. В. Литвинова // Предпринимательство. - 2011. - № 2 (26) - Режим доступу : http://uecs.ru/predprinematelstvo/item/331 2011-03-25-11-54-51 ?pop=1\&tmpl=component\&print $=1$.

8. Москаленко Д. Даешь триллион [Електронний ресурс]/ Д. Москаленко // Бизнес. - 2016. - № 9. - Режим доступу : http:/ /www.business.ua/companies/daesh_trillion-273828/.

9. Нестеров Д. Украинский ритейл: между кризисом и процветанием [Електронний ресурс] / Д. Нестеров. - Режим доступу : //http://retailstudio.-org/.

10. Швестко В. О. Тенденції розвитку корпоративних роздрібних торговельних мереж України [Електронний ресурс] / В. О. Швестко // Ефективна економіка. - 2015. - № 12. - Режим доступу : http://library.sumdu.edu.ua/data/Economic_01_ 2016.docx.

11. Шаповал Е. Супермаркеты отчитываются о росте товарооборота. На деле ситуация в ритейле очень плоха [Електронний ресурс] / Е. Шаповал. - Режим доступу : http:// hubs.ua/business/vy-ruchka-supermarketov-padaet-39517.html.

\section{Будникевич Ирина,}

доктор экономических наук, профессор Черновицякого нацчионального университета им. Ю. Федьковича

Черданцева Ирина,

кандидат экономических наук, дочент Черновицкого начионального университета им. Ю. Федьковича

\section{ФОРМИРОВАНИЕ КОНКУРЕНТНЫХ СТРАТЕГИЙ РАЗВИТИЯ ПРЕДПРИЯТИЙ РОЗНИЧНОЙ ТОРГОВЛИ В ИНСТИТУЦИОНАЛЬНОЙ СРЕДЕ}

В статье рассматриваются возможности применения современных подходов к формированию конкурентныХ стратегий развития предприятий розничной торговли с учетом влияния институциональной среды, ориентированных на использование маркетинговых инструментов при разработке принципов адаптации ритейлеров к меняющимся условиям рынка. Обобщены современные тенденции развития рынка розничной торговли Украины и сделан вывод о наличии негативных трендов, которые определяют стратегии операторов розничной торговли. Описаны принципы работы новых операторов рынка розничной торговли, которые, входя на рынок как инноваторы, постепенно переходят к традиционным "усредненным, типичным" схемам работы. Сделан вывод о необходимости ценностной ориентации (изобретение и обслуживание дополнительной, уникальной полезности для потребителей) конкурентных стратегий развития розничного предприятия.

Ключевые слова: институциональная среда; концепции развития; розничная торговля; маркетинговые инструменты; конкурентные стратегии; стратегии развития розничной торговли; рынок розничной торговли.

Budnikevych Iryna,

Doctor of Economical Sciences, professor, Chernivtsi National University named after Yuriy Fedkovych

Cherdantse va Iryna,

Candidate of Economical Sciences, Associate professor,

Chernivtsi National University named after Yuriy Fedkovych

\section{FORM ATION OF COM PETITIVE STRATEGIES OF ENTERPRISES DEVELOPM ENT OF RETAILSALE IN THE INSTITUTIONAL ENVIRONMENT}

The article regards the possibilities of implementing modern approaches to formation of development strategies of retail sale enterprises with account to influence of institutional environment which is oriented to use of marketing tools while elaborating the principles of retailers' adaptation to changing market conditions. 
It considers the essence of retail sale concept which is a consequence of transformation of consumer oriented marketing concept and consists of four elements - consumer orientation, coordinated activities, value orientation, aspiration to acquire the goals. Special attention is accentuated to the fact that the concept is understood but not all the retail sellers: they do not perceive changes or simply copy the strategies used by their competitors; they do not aspire to investigate the advantages of consumers, study their opinions, and wishes, and completely rely on the suppliers' reports or their previous experience of sales.

The conclusion is drawn that a retail company can rely on success if its competitive advantages correspond to the possibilities of environment where it has to act; if it manages to eliminate (or at least minimize) its weaknesses; if its plans are not only directed to the future and also take into account previous experience. Use of marketing concept in retail sale is possible with shifting of main accent to such notions as general impressions of consumers from the retail company, service to consumers and relationships oriented retail sale.

Main trends of market development of Ukrainian retail sale (significant shortening of sales in the majority of segments of retail sale in the majority of segments of retail sale; raise of percentage of non-organized trade (53\%) are revealed, conclusion is made about presence of negative trends determining the strategies of retail sale operators. The reasons of decrease for different segments of retail sale market are determined: in the "premium" segment - fight for parts of market among competitors, in "medium" segment shift of $70 \%$ of consumers to the segment "medium minus". The conclusion is drawn that retail cooperative networks have to operatively change the assortment, price and distribution policy.

Principles of work of new retail sale operators are described; entering the market as innovators they gradually shift to traditional "medium, typical" schemes of work. It is determined that retail companies presented at the Ukrainian market must aspire to create and sustain the long-term relationships with their clients, and not behave like each next purchase in their shop is performed by a completely alien person to them.

The conclusion is draw about the necessity of value orientation (invention and service of additional, unique usefulness for consumers) of long-term strategies of retail sale enterprise development. It is established that only strict positioning of unique usefulness that will be found by a consumer in a given shop will become the basis of his long-term purchase loyalty and will provide sustainable functioning of a retail company even with negative tendencies at the market; and orientation exclusively towards price proposal will stimulate consumers to constant search of new "price temptations" in other retail points and will again launch the "wheel" of retail sale with other players.

Key words: institutional environment; development concepts; retail sale; marketing tools; retail sale development strategies; retail sale market.

\section{REFERENCES}

1. Ansoff, H. Igor (1987), Strategic management of technology, Journal of Business Strategy, Vol. 7, Iss: 3, 28-39. doi: 10.1108/ eb039162

2. Thirlwall, A. P. and Pacheco-López, P. (2009), Trade Liberalisation and The Poverty of Nations, Edward Elgar, Cheltenham, 264 p. doi: $10.4337 / 9781848444010$

3. Howard, E. (2004), Retail internationalization: how to grow, Retail Strategy. The view from the bridge, 96-118. doi: 10.1016/b9780-7506-5696-2.50007-6

4. Reynolds, J. (2004), Introduction to retail strategy, Retail Strategy. The view from the bridge, 3-22. doi: 10.1016/b978-0-75065696-2.50003-9

5. Samli, A. C. (2015), Coping with Retail Giants. Gaining an Edge Over Discounters, Palgrave Macmillan US, 198 p. doi: $10.1057 /$ 9781137476340

6. Bedrynets, M. D. (2004), Financial support of small business structures, Abstract of thesis for the degree of candidate of economic sciences in specialty 08.04.01, Irpin, 19 p. (ukr).

7. Litvinova, O. V. (2011), Conceptual specifics of network forms of business in trade, Predprinimatelstvo, Vol. 2(26), available at: http://uecs.ru/predprinematelstvo/item/331-2011-03-25-11-54-51 ?pop=1\&tmpl=component\&print=1 (rus).

8. Moskalenko, D. (2015), Give a trillion, Biznes, Vol. 9, available at: http://www.business.ua/companies/daesh_trillion-273828/ (ukr).

9. Nesterov, D. (2010), Ukrainian Retail: between crisis and prosperity, available at: http://retailstudio.org/article/9820 (ukr).

10. Shvestko, V. (2015), Trends in corporate retail trade networks of Ukraine, Efektyvna ekonomika, Vol. 12, available at: http:// library.sumdu.edu.ua/data/Economic_01_2016.docx (ukr).

11. Shapoval, Ye. (2015), Supermarkets report on commodity turnover growth. In fact, the situation is very bad in the retail sector, available at: http://hubs.ua/business/vy-ruchka-supermarketov-padaet-39517.html (ukr).

(C) Буднікевич Ірина, Черданцева Ірина

Надійшла до редакції 26.09.2016 